\title{
Autobiographies and Weak Ties: Sa'in al-Din Turka's Self-Narratives
}

\author{
İlker Evrim Binbaş \\ Institut für Orient- und Asienwissenschaften, Rheinische-Friedrich-Wilhelms-Universität Bonn; \\ ${ }^{\star}$ Corresponding author. E-mail: ebinbas@uni-bonn.de
}

As I write this essay, the forty-fourth US President Barack Obama's autobiography titled A Promised Land is the best-selling book in Germany, in both the German and the English editions. This is his second autobiographical work, following Dreams from My Father in 1995. Given Obama's prominent place in our modern political culture, this is hardly surprising, but today's publishers seem to have no specific criteria for deciding whose life and career are worthy of an autobiography. Any moderately successful individual from any walk of life can publish an autobiography today. The popularity of the genre is certainly related to the extreme glorification of individual and personal success in modern society, but it also shapes how we view premodern self-narratives: as a window into an intellectual's individuality and Bildung. This essay questions this convention and explores the opportunities that self-narratives embedded in literary and narrative sources present to historians of 15th-century Iran and Central Asia. I will argue that autobiographies and self-narratives are much more than tools for refashioning the self in the early modern period. They open a window to a much wider network of weak ties and acquaintances, a closer scrutiny of which may allow us to reconstruct transregional networks, understand the connectedness of these intellectual networks, and delineate their collective identities in the early modern period. ${ }^{1}$ In my discussion I will focus on a selection of 15 th-century texts, most prominently the selfnarratives of the Timurid intellectual Sa'in al-Dīn Turka (d. 1432).

Sa'in al-Din Turka, also known as Ibn Turka, was a member of a notable urban family from Isfahan. He was a prolific author in the field of occult sciences, especially the science of letters ('ilm al-hurüf), and recent research on his oeuvre and intellectual milieu has demonstrated that he was not an exception in his own time. ${ }^{2}$ Rather, he exemplified the kind of Timurid and late medieval Islamic intellectual who placed the science of letters at the center of his scholarly and political vocation. ${ }^{3}$ As the extant manuscript corpus of his writings on the science of letters suggests, his work found a ready audience in almost all the cultural centers of the Persianate world, from Istanbul to Hyderabad, up to the modern period. His unpublished al-Mafahis (The Investigations) is considered a masterpiece of the science of letters in the early modern period. Ibn Turka's oeuvre, especially his short treatises, are replete with autobiographical references, so much so that several of those treatises can almost be considered autobiographical in

\footnotetext{
${ }^{1}$ I borrow the term "weak tie" in this article from Mark Granovetter's seminal research on the importance of acquaintances, or weak ties, in sociological analysis. Granovetter argues that acquaintances are as important as strong ties, such as family, close friends, and patrons, in understanding how networks and social groups functioned. See Mark Granovetter, "The Strength of Weak Ties: A Network Theory Revisited," Sociological Theory 1 (1983): 201-33.

${ }^{2 c} \mathrm{Ilm}$ al-hurüf is a form of science that studies the gnostic and mathematical properties of the letters of the Arabic alphabet. The "scientists of letters" calculate the value of each letter and its gnostic associations to understand the unrevealed hidden meaning of the Qur'an, and to ultimately perceive the secrets of creation.

${ }^{3}$ For recent studies on Ibn Turka's life and works, see Matthew Melvin-Koushki, "The Quest for a Universal Science: The Occult Philosophy of Șāin al-Dīn Turka Ișfahānī (1369-1432) and Intellectual Millenarianism in Early Timurid Iran" (PhD diss., Yale University, 2012); “The Occult Challenge to Philosophy and Messianism in Early Timurid Iran: Ibn Turka's Lettrism as a New Metaphysics," in Unity in Diversity: Patterns of Religious Authority in Islam, ed. Orkhan Mir-Kasimov (Leiden: Brill, 2014), 247-76; and İlker Evrim Binbaş, Intellectual Networks in Timurid Iran: Sharaf al-Dīn 'Alī Yazdī and the Islamicate Republic of Letters (Cambridge, UK: Cambridge University Press, 2016), 140-64.

(c) The Author(s), 2021. Published by Cambridge University Press. This is an Open Access article, distributed under the terms of the Creative Commons Attribution licence (http://creativecommons.org/licenses/by/4.0/), which permits unrestricted re-use, distribution, and reproduction in any medium, provided the original work is properly cited.
} 
nature. ${ }^{4}$ Two treatises are noteworthy for their rich autobiographical contents: Nafsat al-Masdur-i Awwal (The First Tubercular Spittle, hereafter NM I) and Nafsat al-Masdur-i Duvvum (The Second Tubercular Spittle, henceforth NM II). ${ }^{5}$ Ibn Turka finished writing NM I on 16 May 1426 in Herat and addressed it to Shahrukh (1377-1447), son of Timur. It is rather difficult to establish when Ibn Turka wrote NM II, which he dedicated to Baysunghur (1397-1433), son of Shahrukh. Its contents suggest that it was written sometime after 1426-27 and before 1431-32, the year in which Ibn Turka died. The dates of composition are significant for our purposes, but for a moment, let's hear, albeit briefly, what kind of stories these treatises tell us about Ibn Turka and his life.

NM I comprises an introduction and two chapters on the prohibition of innovation (bid'a) in religion and on aphorisms of Sufi masters. The autobiographical information is mainly found in the introductory section. According to these references, Ibn Turka studied traditional Islamic sciences alongside his brother. He went to Herat twice to defend himself before Shahrukh against certain accusations by his rivals in Yazd. ${ }^{6}$ The references on Ibn Turka's life are not more abundant in NM II, but here again he defends himself against his critics and tries to clear himself in the face of his accusers' allegations, and gives more details about himself, his family, and their background. For instance, he informs Baysunghur that his family hailed from Khujand in Central Asia, that he traveled for fifteen years in pursuit of learning and education, and that upon his return to 'Iraq-i 'Ajam he entered the service of the 'Umar Shaykhid-Timurid rulers of the region, first Pir Muhammad b. 'Umar Shaykh (d. 1409) and then Iskandar b. 'Umar Shaykh (d. 1415). ${ }^{7}$ We know from other contemporary sources that Ibn Turka was a prominent member of Iskandar's entourage, but this fact is not emphasized in NM II because Iskandar clashed with his uncle Shahrukh over the throne of Timur in 1416. After losing the competition, Iskandar perished at the hands of his own brother Rustam. The allegations against Ibn Turka are emphasized in NM II as well. This time Ibn Turka even names one of his accusers: the famous scholar Ibn al-Jazari (d. 1429), about whom I will say more shortly. In NM II Ibn Turka tries to explain his views on Sufism and distances himself from the radical Hurufi movement of Fazl Allah Astarabadi (d. 1394). ${ }^{8}$

It is now time to expand our view of Ibn Turka's self-narratives and look at the broader context in which he composed these treatises. ${ }^{9}$ This should allow us to make sense of his cryptic comments about accusations, allegations, and attacks. It also will shed light on a novel intellectual perspective that Ibn Turka proposes. Ibn Turka wrote NM I and NM II at a time of political and constitutional crisis in the Timurid Empire, when Shahrukh's political project underpinned by a contractual political ideology clashed with the influence of growing informal intellectual networks. Events started unfolding in earnest when Timur died on 17 February 1405. Timur managed to create a sizable empire, but just like his role model, Chinggis Khan (d. 1227), he failed to leave behind a binding constitutive political framework for his successors. The period between 1405 and 1421, the first Timurid civil war, witnessed a clash of competing political programs and constitutional frameworks such as the Chinggisid and caliphal projects. Shahrukh emerged victorious from the civil war and eliminated other pretenders to Timur's throne, but he found himself challenged by informal intellectual networks that often included figures among their denizens who saw the occult sciences as a vocation, if not a profession. The clash between the Timurid monarch and the informal networks of scholars reached its apex on 21 February 1427, when a group of Hurufis tried to assassinate Shahrukh. The assassination attempt was unsuccessful, but Shahrukh blamed all the intellectuals who had studied the science of letters for the calamity that had

\footnotetext{
${ }^{4}$ Most of Ibn Turka's short treatises were published in the following collection: Sa'in al-Din Turka, Chahardah Risala-i Farsi az Sa'in al-Din 'Ali b. Muhammad Turka Isfahani, ed. Sayyid 'Ali Musawi Bihbihani and Sayyid Ibrahim Dibaji (Tehran: Chapkhana-i Firdawsi, 1972).

${ }^{5}$ NM I: ibid., 167-94; NM II: ibid., 195-217.

${ }^{6} \mathrm{NM} I, 170-72$.

${ }^{7} \mathrm{NM}$ II, 203-4.

${ }^{8}$ Ibid.

${ }^{9}$ This paragraph is based on my earlier research published in 2014. See İlker Evrim Binbaş, "The Anatomy of a Regicide Attempt: Shāhrukh, the Hurūfiss, and the Timurid Intellectuals in 830/1426-27," Journal of the Royal Asiatic Society, series 3 (2013): 1-38. The purges resonate in contemporary and near contemporary chronicles, but our most important sources for this event are the references in the works of those affected intellectuals. The list includes, besides Ibn Turka and the arrested Hurufis, Qasim-i Anwar (d. 1433), Husayn Khwarazmi (d. 1435), and Sharaf al-Din 'Ali Yazdi (d. 1454).
} 
befallen him and launched a widespread purge of those intellectuals who were deemed to harbor dangerous intentions through their practice of the science of letters. Ibn Turka was among those intellectuals who were implicated during the investigations, and he had to travel to Herat from Isfahan to defend himself against his accusers.

What concerns us here is not the specifics of the events that led to a very violent episode in Timurid social and intellectual history, but how Ibn Turka defended himself against the accusations. Ibn Turka argued that he was not the only intellectual who believed in the science of letters and that in other parts of the Islamic world, in the Ottoman lands to be precise, the science of letters was tolerated and even encouraged. He named in particular Mulla Shams al-Din Fenari (d. 1431), whom Ottoman historiography considers the first shaykh al-Islam of the Ottoman Empire. Mulla Fenari was a legal scholar and Sufi, in the school of Ibn 'Arabi, and was held in high esteem in the Ottoman Empire. In Ibn Turka's view, this was a sign of the Ottomans' tolerance and consequently a reference point for the Timurids' intolerance toward the science of letters. Ibn Turka's views on the liberality of the Ottoman system cannot be substantiated, as we know that even Mulla Fenari felt insecure in the Ottoman lands, especially after Shaykh Bedreddin's revolt in 1416, but that should not concern us for the time being. What is important for our purposes is that Ibn Turka imagined and positioned himself in a wide-ranging and expansive intellectual network that had a presence in the central Islamic lands of the early 15th century. Ibn Turka's attempts to locate himself in a broader network of intellectuals indicated more than simply deflecting blame; we have no evidence to suggest that he felt guilty of anything. Rather, he was trying to define his own self with reference to a broader set of intellectual endeavors common to numerous like-minded people with whom he shared certain philosophical, political, and aesthetic values, most of whom he had never met. By including self-narratives in his treatises, Ibn Turka does not merely open a window into his own inner life and thoughts, but also (perhaps more importantly) draws a map of the network in which his intellectual life flourished. I believe this should lead us to rethink our basic understanding of the individual or intellectual persona of the early modern period, going beyond the simplistic liberal notion of an independent individual devoid of any associations with the environment.

Ibn Turka was not alone in situating his intellectual persona in a broader social and intellectual network. 'Abd al-Rahman al-Bistami (d. 1454) was another prominent occultist of the late medieval period. He was born in Antioch and studied in Damascus and Cairo. He entered the At'ani-Bistami Sufi network centered around Aleppo and began his studies in the occult sciences in the same intellectual circles. He later went to Bursa, to the court of Murad II (r. 1421-44, 1446-51), and played a foundational role in the formation of Ottoman intellectual life after the conquest of Constantinople. ${ }^{10}$ Just like Ibn Turka, al-Bistami peppers his works with references to his life and activities. A single and probably unique manuscript deserves to be called an intellectual self-narrative in the true sense of the word. Durrat Taj al-Rasa'il (The Pearl in the Crown of Treatises) gives a detailed account of all the books that al-Bistami studied to become a proper occultist in his own time. ${ }^{11}$ The list includes many obscure hermetic titles, which are unknown to us but apparently were part of an early modern curriculum of the occult sciences. ${ }^{12}$ Here, the more relevant aspect of the Durrat is that al-Bistami gives an account of his travels and names the intellectuals whom he visited. This is a unique firsthand description of an informal intellectual network by one of the members of the network itself. The names mentioned in this treatise include many intellectuals, some of whom have already been mentioned, such as Mulla Fenari and

\footnotetext{
${ }^{10}$ Once a largely overlooked figure, there is now a relatively substantial literature on al-Bistami and his oeuvre, but none of his works on the occult sciences has yet been properly edited. This is a significant challenge for those of us who are interested in his life and ideas. See İhsan Fazlığlu, "İlk dönem Osmanlı ilim ve kültür hayatında İhvanu’s safa ve Abdurrahman Bistami," Divan 1, no. 2 (1996): 229-40; Noah Gardiner, "Occultist Encyclopedism of 'Abd al-Raḥmān al-Bisțāmī," Mamluk Studies Review 20 (2017): 3-38; Cornell H. Fleischer, "A Mediterranean Apocalypse: Prophecies of Empire in the Fifteenth and Sixteenth Centuries," Journal of the Economic and Social History of the Orient 61 (2018): 18-90; and Noah Gardiner, "Lettrism and History in 'Abd al-Raḥmān al-Bisțāmī’s Naẓm al-sulūk fì musāmarat al-mulūk," in Islamicate Occult Sciences in Theory and Practice, ed. Liana Saif et al. (Leiden: Brill, 2021), 230-66.

${ }^{11}$ Abd al-Rahman al-Bistami, Durrat Taj al-Rasa'il (Istanbul: Süleymaniye Kütüphanesi Ms. Nuruosmaniye, 4905).

${ }^{12}$ A similar list is included in al-Bistami's Shams al-Afaq. Gardiner published this list in 2017 but, as he says, the list in the Durrat requires a separate study ("Occultist Encyclopedism," 30-38).
} 
Shaykh Bedreddin Simavnevi. What is more interesting is that al-Bistami ascribes a group identity to this network and calls it Ikhwan al-Safa' wa Khillan al-Wafa' (Brethren of Purity and Friends of Sincerity). There is no doubt that the members of this informal group were aware of the Rasa'il Ikhwan al-Safa', the 10th-century occult philosophical compendium arguably written by a similar group of intellectuals who had strong inclinations toward the occult sciences. The most important difference between the 10th-century Ikhwan and the 15th-century Ikhwan is the fact that al-Bistami did not conceal the identity of his peers.

A similar strategy of embedding a self-narrative into a broader intellectual network was adopted by al-Bistami's contemporary, Shams al-Din Muhammad ibn al-Jazari (1350-1429). ${ }^{13}$ Ibn al-Jazari was born in Damascus and studied in his hometown and in Cairo. During his career he achieved great fame and success as a scholar of Qur'anic recitation and hadith, and he performed various administrative duties during the reign of the Mamluk sultan Barquq (r. 1382-89, 1390-99). In 1396 Ibn al-Jazari left the Mamluk domains in Alexandria and went to Bursa. In his words, he was invited by the Ottoman sultan Bayezid I (r. 1389-1402), but according to Mamluk sources he escaped prosecution for embezzling endowment funds in Damascus. In Bursa Ibn al-Jazari tutored Bayezid I's children and taught them Arabic, but his residence at Bayezid's court was cut short when Timur invaded Anatolia and defeated Bayezid at the Battle of Ankara in 1402. Ibn al-Jazari joined Timur's camp after the battle and went to Samarkand. When Timur died in 1405, Ibn al-Jazari left Samarkand and settled in Shiraz, where he lived until his death in 1429. Ibn al-Jazari emphasized the importance of the chain of transmission (isna $\bar{d}$ ) in his studies on Quranic recitation and hadith, and he actually composed one of the most important biographical dictionaries dedicated to the scholars of Qur'anic recitation, titled Ghayat al-Nihaya fi Tabaqat al-Qurra' (The Ultimate Outcome of the Generations of Qur'an Reciters). What is curious about this work is that Ibn al-Jazari included his own biography in the long genealogical chain of Qur'an reciters. ${ }^{14}$ The format of the self-narrative included in the Ghayat is detailed, although not regarding the details of his life and relationships. Ibn al-Jazari appears to be locating his intellectual persona in a diachronic narrative setting following a long chain of transmission going back to the first century of Islam. $^{15}$ In his later work, the Jamic al-Asanid (Compendium of the Chains of Transmission), Ibn al-Jazari is more candid about the details of his life in the three polities of his time, that is, the Mamluks, Ottomans, and Timurids. He composed this work to demonstrate the importance of the chain of transmission, and in it he presents his readers with a relatively detailed selfnarrative. ${ }^{16}$ It is true that he may have had ulterior motives for including such a detailed self-narrative. He left Cairo under dubious circumstances and was probably worried about his legacy as well as the material wealth he left behind in the Mamluk sultanate. We know that after his death his influential son Muhibb al-Din Abi al-Khayr (d. 1450) tried to recover his father's confiscated properties in Cairo and Bilad al-Sham. ${ }^{17}$ This explains why Ibn al-Jazari included such vivid details in his self-narrative, such as how he accompanied Bayezid I to Constantinople when the city was under siege by the Ottoman armies. However, it provides very little justification for including this self-narrative in a study on the importance of chains of transmission. It is my contention that Ibn al-Jazari defined his intellectual persona in a diachronic manner and situated himself at the end of long tradition of scholars who, in his view, were the backbone of the Islamic community throughout history.

Perhaps any essay on self-narratives, or autobiographies, must include an obligatory reference to Jacob Burckhardt (1818-97) and his seminal assessment on the rise of individualism in the 15th century. Burckhardt argued that the political diversity and constitutional plurality in late medieval Europe, especially on the Italian peninsula, created an environment in which scholars and artists could experiment

\footnotetext{
${ }^{13} \mathrm{I}$ studied and partially translated into English the sources mentioned in this paragraph in a previous article on the Battle of Nicopolis in 1396. See İlker Evrim Binbaş, "A Damascene Eyewitness to the Battle of Nicopolis: Shams al-Dīn Ibn al-Jazarī (833/ 1429)," in Contact and Conflict in Frankish Greece and the Aegean 1204-1453, ed. Nikolaos G. Chrissis and Mike Carr (Reading, UK: Ashgate, 2014), 153-75.

${ }^{14}$ Ibn al-Jazari, Ghayat al-Nihaya fi Tabaqat al-Qurra', 3 vols., ed. G. Bergstraesser and Otto Pretzl (Cairo: Maṭba'at al-Sa'cadah, 1933-37), vol. 2, 247-49.

${ }^{15}$ The biography of Ibn al-Jazari's son, Abu al-Fath ibn al-Jazari, is also included in the book (ibid., vol. 2, 251-53).

${ }^{16}$ Ibn al-Jazari, Jami al-Asanid (Istanbul: Süleymaniye Kütüphanesi Ms. Darülmesnevi 11).

${ }^{17}$ Binbaş, "Damascene Eyewitness," 164.
} 
with ideas that paved the path for the development of individualism. However, as Cemal Kafadar warned us, the early modern Islamicists believed that individuals existed in broader groups and that the boundary between the self and society was a dynamic one. It shifted and was redrawn in different times and contexts. ${ }^{18}$ These boundaries were delineated either synchronically, as in the self-narratives of Ibn Turka, or diachronically, as in the case of Ibn al-Jazari. Sometimes they were set both diachronically and synchronically, as al-Bistami tried to achieve by naming his network after a comparable informal network that existed in the Islamic medieval period. Self-narratives give us an opportunity to map out informal associations and the weak ties that constituted the skeleton of these networks, in which peers and friends play roles as important as those of patrons and masters in the formation of intellectuals.

\footnotetext{
${ }^{18}$ Cemal Kafadar, "Self and Others: The Diary of a Dervish in Seventeenth Century Istanbul and First-Person Narratives in Ottoman Literature,” Studia Islamica 69 (1989): 135.
}

Cite this article: Binbaș IE (2021). Autobiographies and Weak Ties: Sa'in al-Din Turka's Self-Narratives. International Journal of Middle East Studies 53, 309-313. https://doi.org/10.1017/S0020743821000362 